\title{
Isospora coerebae n. sp. (Apicomplexa: Eimeriidae) from the bananaquit Coereba flaveola (Passeriformes: Coerebidae) in South America
}

\author{
Isospora coerebae n. sp. do caga-sebo Coereba flaveola (Passeriformes: Coerebidae) na América do Sul \\ Bruno Pereira Berto ${ }^{1}$; Walter Flausino ${ }^{1}$; Hermes Ribeiro Luz ${ }^{2}$; Ildemar Ferreira ${ }^{2}$; Carlos Wilson Gomes Lopes ${ }^{1 *}$ \\ ${ }^{1}$ Departamento de Parasitologia Animal, Instituto de Veterinária, Universidade Federal Rural do Rio de Janeiro - UFRRJ \\ ${ }^{2}$ Departamento de Biologia Animal, Instituto de Biologia, Universidade Federal Rural do Rio de Janeiro - UFRRJ
}

Received June 29, 2010

Accepted December 9, 2010

\begin{abstract}
The present study describes a new isosporoid coccidian parasite from the bananaquit Coereba flaveola, in Brazil. This new species is similar to $I$. cagasebi, but it can be distinguished by the size and shape of Stieda and susbstieda bodies. Isospora coerebae $\mathrm{n}$. sp. oocysts are spheroidal to sub-spheroidal, $24.8 \times 23.3 \mu \mathrm{m}$, with a smooth and bi-layered wall, $-1.2 \mu \mathrm{m}$. Micropyle, oocyst residuum and polar granule are absent. Sporocysts are elongate ovoidal, $17.9 \times 10.9 \mu \mathrm{m}$. Stieda and substieda bodies are present. Sporocyst residuum is present and sporozoites have a posterior refractile body.

Keywords: Passeriformes, Coerebidae, oocysts, Marambaia Island, Brazil.

\section{Resumo}

Um novo parasito coccídio isosporóide do caga-sebo Coereba flaveola, do Brasil, é relatado no estudo atual. Essa nova espécie é semelhante à Isospora cagasebi, no entanto, pode ser distinguida pelos tamanho e forma dos corpos de Stieda e substieda. Os oocistos de $I$. coerebae n. sp. são esféricos a subesféricos, $24,8 \times 23,3 \mu \mathrm{m}$, com parede dupla e lisa, - 1,2 $\mu \mathrm{m}$. A micrópila, resíduo e grânulo polar do oocisto estão ausentes. Os esporocistos são ovóides alongados, $17,9 \times 10,9 \mu \mathrm{m}$. Os corpos de Stieda e substieda estáo presentes. O resíduo do esporocisto está presente e os esporozoítos possuem um corpo refrátil posterior.
\end{abstract}

Palavras-chave: Passeriformes, Coerebidae, oocistos, Ilha da Marambaia, Brasil.

\section{Introduction}

The bananaquit Coereba flaveola Linnaeus, 1758 is a small honeycreeper in the family Coerebidae. It is common in and around gardens where flowers are abundant. It adapts well to human activity, and lives in borders of open country, plantations, towns and forests (SICK, 1997; RAFFAELE et al., 1998).

Coccidiosis in this host family is rare with only a single species, Isospora cagasebi Berto, Flausino, Luz, Ferreira, Lopes, 2008, described by Berto et al. (2008) infecting a bananaquit of Brazil.

It is here described a new Isospora species named Isospora coerebae and also I. cagasebi infecting the bananaquit C. flaveola from Marambaia Island, Rio de Janeiro State, Brazil and the characteristics of Stieda and substieda bodies that differentiate these two coccidia.

*Corresponding author: Carlos Wilson Gomes Lopes

Departamento de Parasitologia Animal, Instituto de Veterinária,

Universidade Federal Rural do Rio de Janeiro - UFRRJ,

BR-465, Km 7, CEP 23890-000, Seropédica - RJ, Brazil;

e-mail: lopescwg@ufrrj.br

\section{Material and Methods}

Eight bananaquits were captured using nets on Marambaia Island ( $23^{\circ} 04^{\prime} \mathrm{S}$ and $\left.43^{\circ} 53^{\prime} \mathrm{W}\right)$. They were kept in individual cages, and feces were collected immediately after defecation. After identification the birds were released, and fecal samples were placed into plastic vials containing $2.5 \%(\mathrm{w} / \mathrm{v})$ solution of $\mathrm{K}_{2} \mathrm{Cr}_{2} \mathrm{O}_{7}$ in 1:6 (v/v). Samples were sent for analysis at the Coccidia and Coccidiosis Laboratory at Universidade Federal Rural do Rio de Janeiro (UFRRJ). They were placed in a thin layer $(-5 \mathrm{~mm})$ of $\mathrm{K}_{2} \mathrm{Cr}_{2} \mathrm{O}_{7} 2.5 \%$ solution in Petri plates, and incubated at $23-28{ }^{\circ} \mathrm{C}$ for 10 days or until $70 \%$ of oocysts were sporulated. Oocysts were recovered by flotation in Sheather's sugar solution (S.G. 1.20) and microscopically examined using the technique described by Duszynski and Wilber (1997). Morphological observations (micropyle $[\mathrm{M}]$, oocyst residuum [OR], polar granule [PG], Stieda body [SB], substieda body [SSB], parastieda body [PSB], sporocyst residuum [SR], sporozoite [SZ], refractile body [SRB], nucleus $[\mathrm{N}]$ ) and measurements, in $\mu \mathrm{m}$, were performed using a binocular microscope Carl Zeiss with apochromatic oil immersion objective lens and ocular micrometer (K-15X PZO, Poland). Line 
drawings were prepared using a binocular microscope Wild M-20 with drawing tube. Pictures were taken using a digital camera (Model CD Mavica MVC-CD250 Sony ${ }^{\circledR}$ ). Size ranges are shown in parenthesis followed by average and shape index (L/W ratio). Means comparisons of Stieda and substieda bodies by Student's $t$-test were performed using Excel XP (Microsoft Co., Redmond, WA, USA), as proposed by Sampaio (2002).

\section{Results}

Three of eight $C$. flaveola examined shed oocysts in their feces. All oocysts were typical for the genus Isospora. Two types of oocysts were recorded, each type was detected in two birds, and the third bird presented a mixed infection. The first type of oocysts was identified as Isospora cagasebi. The second type of oocysts could be well recognized from $I$. cagasebi and seemed to represent an unknown species, the description of which follows.

\section{Isospora cagasebi Berto, Flausino, Luz, Ferreira, Lopes, 2008} (Figures 1a-d, 3a-c)

Description of a sporulated oocyst: Oocyst shape ( $\mathrm{N}=11)$ : spheroidal to sub-spheroidal; number of walls: 2 ; wall thickness: 1.3 (1.1-1.3); smooth outer wall about $2 / 3$ of total thickness; $\mathrm{L} \times \mathrm{W}: 25.2 \times 24.5(23-27 \times 23-25)$, with L/W ratio: 1.0 (1.0-1.1); M, OR, PG: all absent.
Description of a sporocyst and sporozoites: Sporocyst shape $(\mathrm{N}=11)$ : elongate ovoidal or ellipsoidal; $\mathrm{L} \times \mathrm{W}$ : $18.7 \times 11.4(17-20 \times 10-12) ; \mathrm{L} / \mathrm{W}$ ratio: $1.6(1.5-1.7) ; \mathrm{SB}$ : present and knob-like; SSB: present and prominent (Table 1); PSB: absent; SR: present; SR characteristics: composed of many scattered granules of different sizes; SZ: vermiform with SRB and N.

Host: Coereba flaveola Linnaeus, 1758 (Passeriformes: Coerebidae), captured on January 13, 2009.

Materials: Oocysts stored in 10\% aqueous buffered formalin (v/v), and deposited in the Parasitology Collection at the Department of Animal Parasitology at UFRRJ, Seropédica, Rio de Janeiro, Brazil. Phototypes and line drawings are deposited at the same location. The repository number is 07/2009.

Locality: Marambaia Island ( $23^{\circ} 04^{\prime} \mathrm{S}$ and $\left.43^{\circ} 53^{\prime} \mathrm{W}\right)$, Rio de Janeiro, Brazil.

Sporulation time: Four days.

Site of infection: Not investigated.

Prevalence: $25 \%$ (two of eight birds examined).

\section{Isospora coerebae n. sp. (Figures 2a-d, 3d-f)}

Description of a sporulated oocyst: Oocyst shape $(\mathrm{N}=14)$ : spheroidal to sub-spheroidal; number of walls: 2 ; wall thickness: 1.2 (1.1-1.3); smooth outer wall about $2 / 3$ of total thickness; $\mathrm{L} \times \mathrm{W}: 24.7 \times 23.3(23-27 \times 21-26)$, with L/W ratio: 1.1 (1.0-1.1); M, OR, PG: all absent.

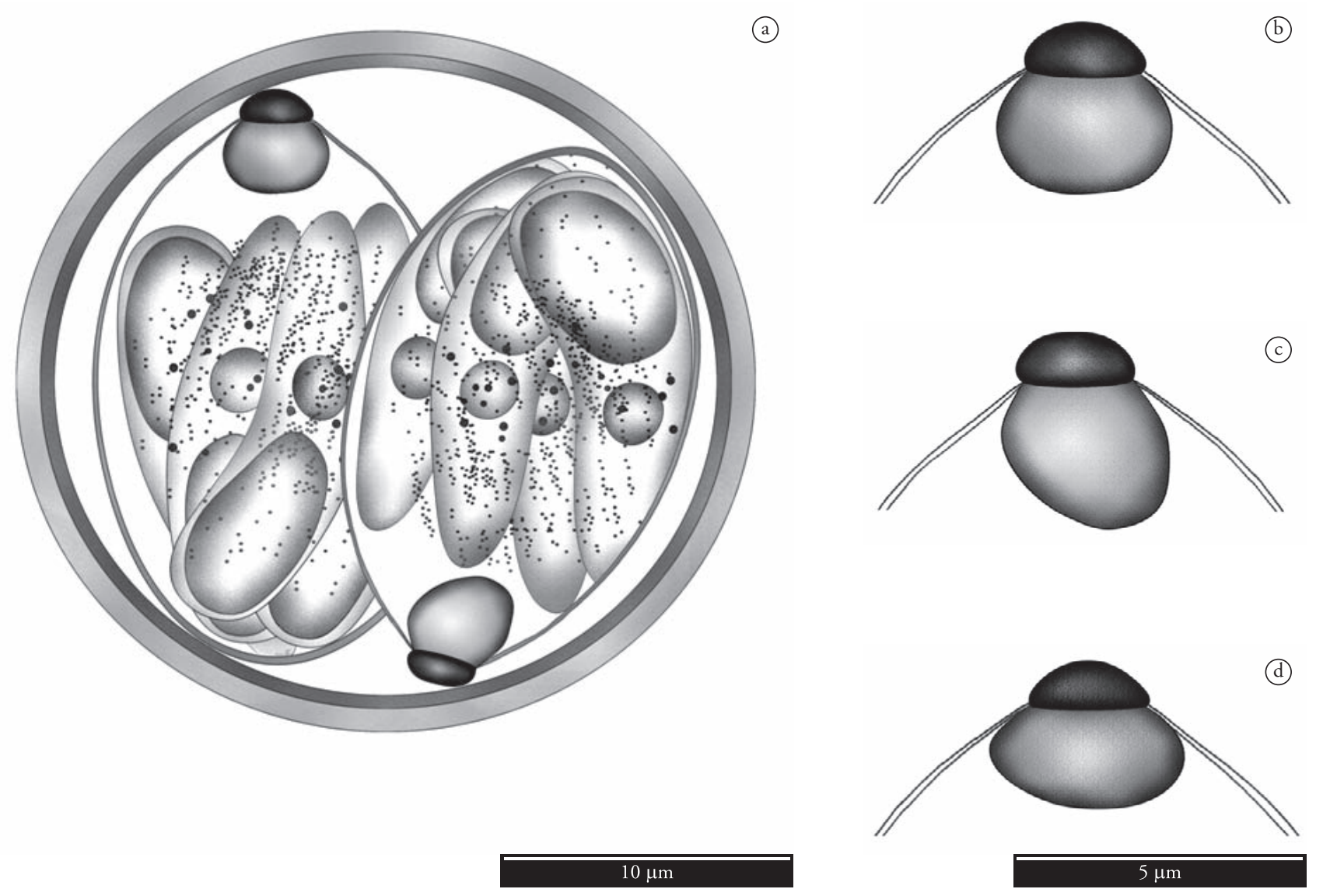

Figure 1. Line drawings of Isospora cagasebi, a coccidium species recovered from the bananaquit Coereba flaveola. (a) Sporulated oocyst with its respective variations of (b, c, d) detached Stieda and substieda bodies. Scale bar: $10 \mu \mathrm{m}$ for oocysts; and $5 \mu \mathrm{m}$ for Stieda and substieda bodies. 
Table 1. Means comparisons of Stieda and substieda bodies of Isospora cagasebi and I. coerebae n. sp. recovered from bananaquit Coereba flaveola.

\begin{tabular}{|c|c|c|c|c|}
\hline \multirow{2}{*}{\multicolumn{3}{|c|}{ Means }} & \multicolumn{2}{|c|}{ Oocyst samples $(\mu \mathrm{m})$} \\
\hline & & & I. coerebae $(\mathrm{n}=11)$ & I. cagasebi $(\mathrm{n}=11)$ \\
\hline \multirow[t]{6}{*}{ Oocyst } & Shape & & spheroidal to sub-spheroidal & spheroidal to sub-spheroidal \\
\hline & Length & & $24.7(23-27)^{\mathrm{a}}$ & $25.2(23-27)^{\mathrm{a}}$ \\
\hline & Width & & $23.3(21-26)^{a}$ & $24.5(23-25)^{a}$ \\
\hline & Shape index & & $1.1(1.0-1.1)^{\mathrm{a}}$ & $1.0(1.0-1.1)^{\mathrm{b}}$ \\
\hline & Wall & & bi-layered, $\sim 1.2$ & bi-layered, -1.3 \\
\hline & Polar granule & & absent & absent \\
\hline \multirow[t]{11}{*}{ Sporocyst } & Shape & & elongate ovoidal & elongate ovoidal or ellipsoidal \\
\hline & Length & & $17.7(16-19)^{\mathrm{a}}$ & $18.7(17-20)^{\mathrm{b}}$ \\
\hline & Width & & $10.9(10-12)^{\mathrm{a}}$ & $11.4(10-12)^{\mathrm{a}}$ \\
\hline & Shape index & & $1.6(1.5-1.8)^{\mathrm{a}}$ & $1.6(1.5-1.7)^{\mathrm{a}}$ \\
\hline & Stieda body & Shape & prominent and rounded & knob-like \\
\hline & & High & $1.2(0.9-1.4)^{\mathrm{a}}$ & $0.9(0.7-1.2)^{\mathrm{b}}$ \\
\hline & & Wide & $1.9(1.7-2.1)^{\mathrm{a}}$ & $2.0(1.9-2.1)^{\mathrm{b}}$ \\
\hline & Substieda body & Shape & short and widely & prominent \\
\hline & & High & $1.2(0.9-1.3)^{\mathrm{a}}$ & $2.3(2.0-2.6)^{b}$ \\
\hline & & Wide & $4.0(3.6-4.5)^{a}$ & $2.9(2.6-3.3)^{\mathrm{b}}$ \\
\hline & Residuum & & diffuse & diffuse \\
\hline
\end{tabular}

${ }^{a}$ Different letters in each line denote statistically significant differences $(\mathrm{p}<0.01)$ by the Student's $t$-test.
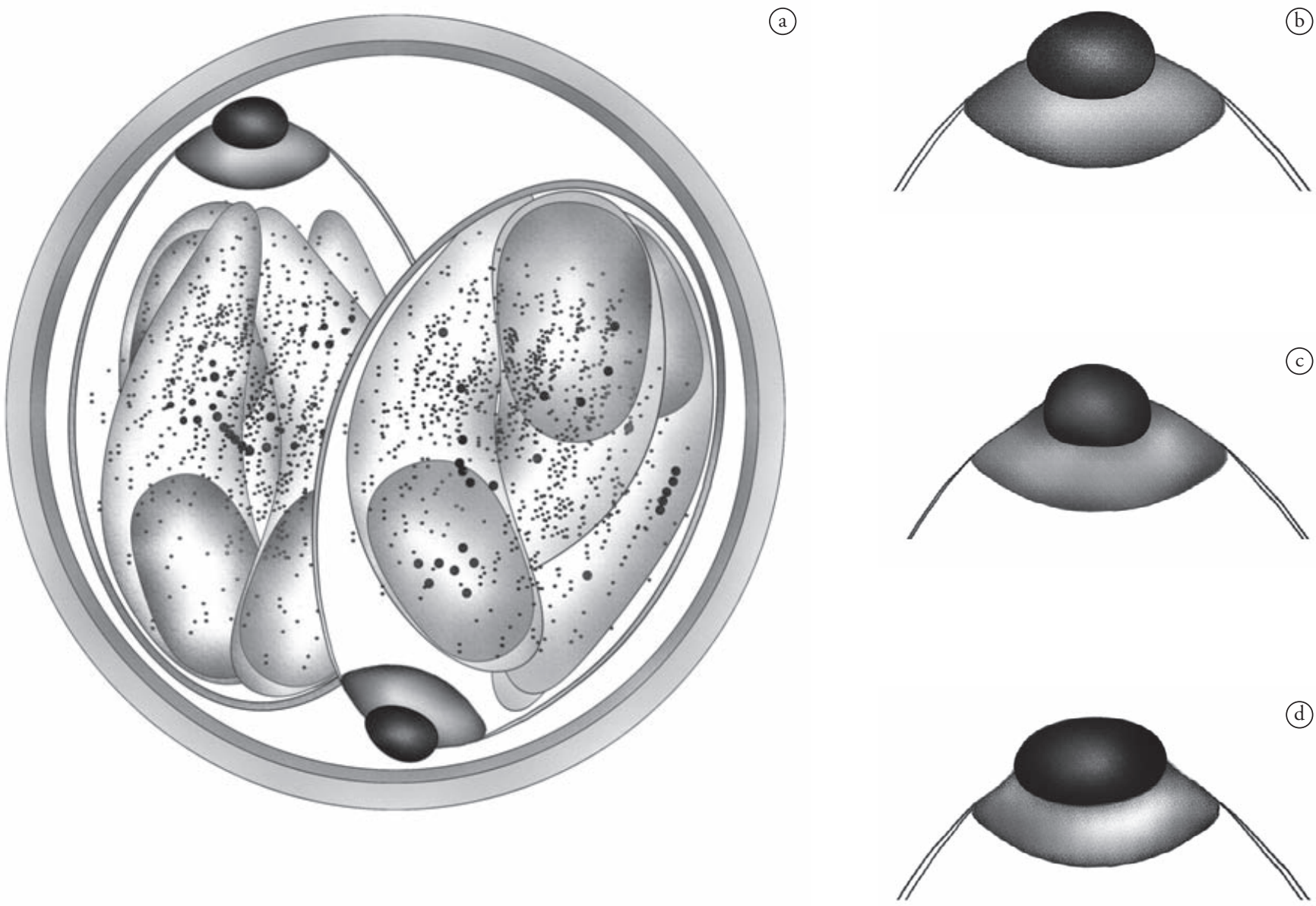

(d)

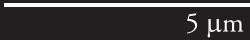

Figure 2. Line drawings of Isospora coerebae, a new coccidium species recovered from the bananaquit Coereba flaveola. (a) Sporulated oocyst with its respective variations of $(b, c, d)$ detached Stieda and substieda bodies. Scale bar: $10 \mu \mathrm{m}$ for oocysts; and $5 \mu \mathrm{m}$ for Stieda and substieda bodies. 

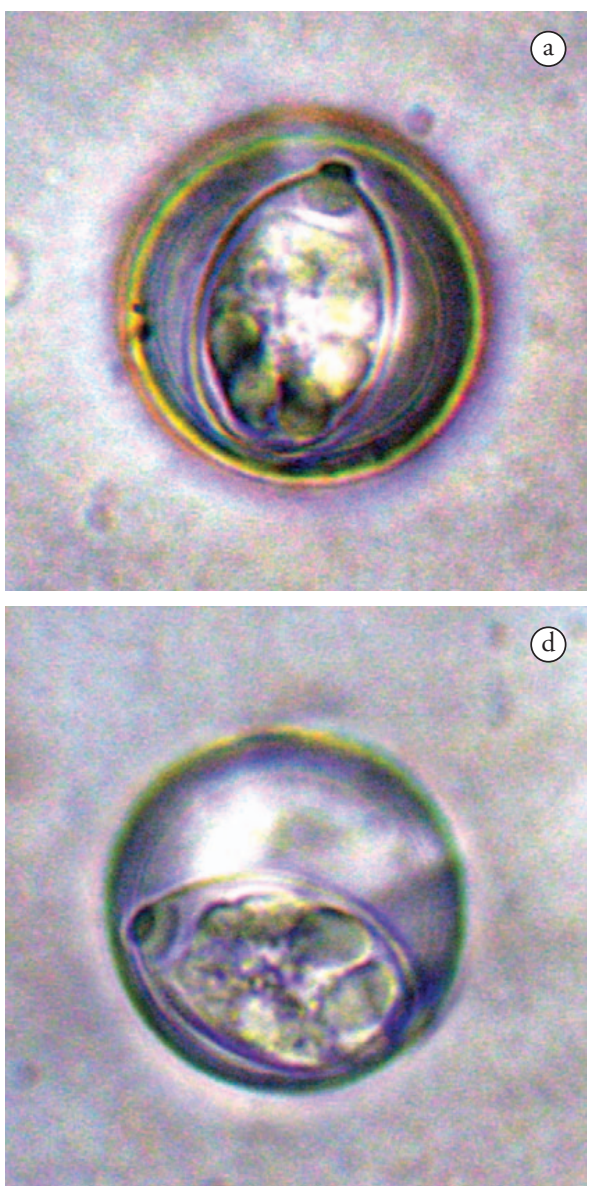
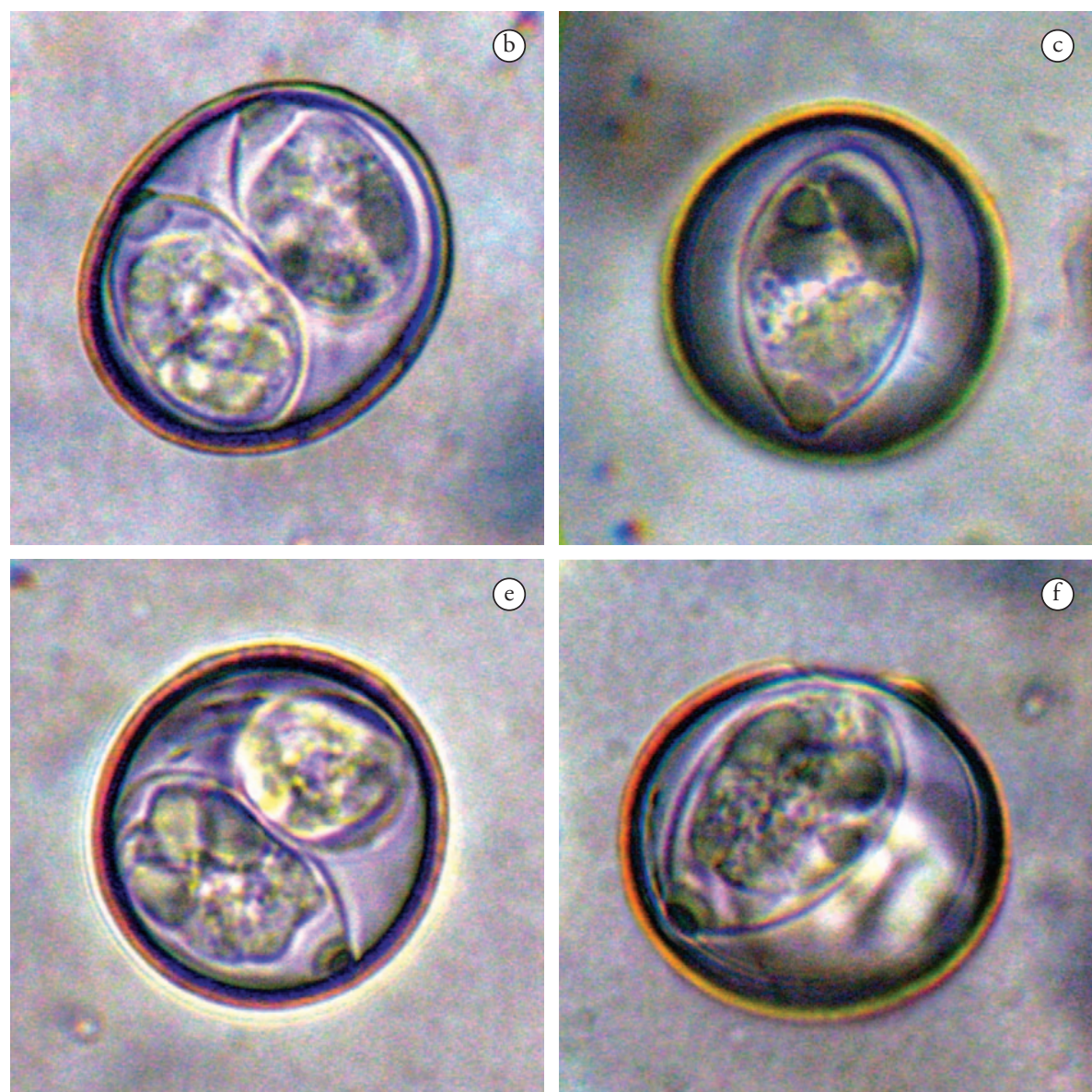

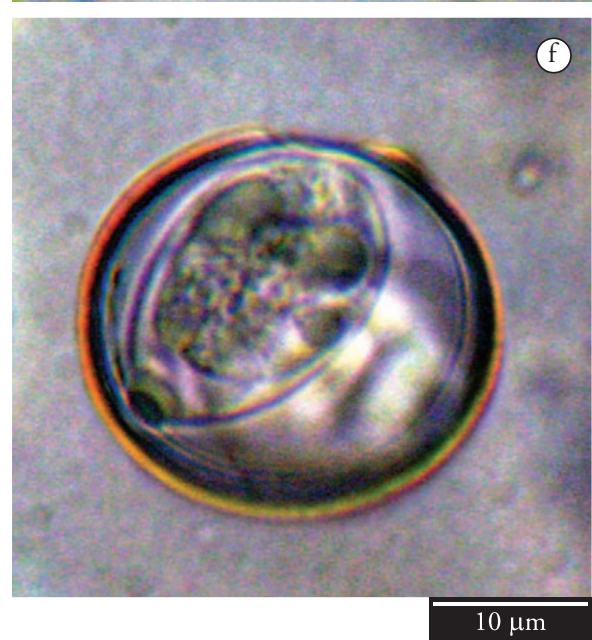

Figure 3. Photographs of sporulated oocysts of coccidia species recovered from the bananaquit Coereba flaveola. (a, b, c) Isospora cagasebi and (d, e, f) I. coerebae. Scale bar: $10 \mu \mathrm{m}$.

Description of a sporocyst and sporozoites: Sporocyst shape $(\mathrm{N}=14)$ : elongate ovoidal; $\mathrm{L} \times \mathrm{W}: 17.7 \times 10.9$ $(16-19 \times 10-12)$; L/W ratio: 1.6 (1.5-1.8); SB: present, prominent and rounded; SSB: present, short, however widely (Table 1); PSB: absent; SR: present; SR characteristics: composed of many scattered granules of different sizes; SZ: vermiform with a posterior SRB.

Type host: Coereba flaveola Linnaeus, 1758 (Passeriformes: Coerebidae), captured on January 13, 2009.

Type material: Oocysts stored in 10\% aqueous buffered formalin (v/v), and deposited in the Parasitology Collection at the Department of Animal Parasitology at UFRRJ, Seropédica, Rio de Janeiro, Brazil. Phototypes and line drawings are deposited at the same location. The repository number is $\mathrm{P}-32 / 2009$.

Type locality: Marambaia Island ( $23^{\circ} 04^{\prime} \mathrm{S}$ and $\left.43^{\circ} 53^{\prime} \mathrm{W}\right)$, Rio de Janeiro, Brazil.

Sporulation time: Four days.

Site of infection: Not investigated.

Prevalence: 25\% (two of eight birds examined).

Etymology: The specific epithet is derived from the generic name of the host type.
Comments: The I. coerebae oocysts can be basically distinguished by the shape of SB and SSB. Isospora cagasebi oocysts present knob-like SB and prominent SSB, while I. coerebae has rounded, short and widely SB and SSB.

\section{Discussion}

The new species described in this present study is close to I. cagasebi. At 400x magnification it is not possible to distinguish oocysts of the two species, however, at $1000 \times$ magnification two distinct types of SB and SSB are visualized. Thus, the I. cagasebi oocyst was redrawn, with details of SB and SSB, for comparison with the new species I. coerebae. Means comparisons of Stieda and substieda bodies between these species confirmed that each species can be distinguished morphologically and morphometrically, as significant differences among all analyzed parameters were found (Table 1).

These results are similar to those reported by Grulet, Landau and Baccam (1982), where 12 species of Isospora were described from the domestic sparrow Passer domesticus Linnaeus, 1758. These authors identified these species mainly by the Stieda 
and substieda complex. According to Duszynski and Wilber (1997), new coccidian species should be compared in detail with coccidian species that are feature-similar and belong to the same host family. Due to the lack of descriptions of coccidia in Coerebidae family, I. coerebae was only compared with I. cagasebi.

The Coerebidae family is grouped into a single species, C. flaveola; however it can be approached to the Thraupidae and Emberezidae families (BURNS; HACKETT; KLEIN, 2003; CBRO, 2009). Thus, Berto et al. (2008) compared I. cagasebi with coccidian species parasites of these two families. These comparisons are equally valid to $I$. coerebae. Up to date the coccidia support the classification of $C$. flaveola in an exclusive family since coccidia of coerebids have not yet been reported in thraupids and emberezids.

\section{Acknowledgements}

We thank the Brazilian Navy, especially CADIM (Centro de Adestramento da Ilha da Marambaia) commander who authorized our access to Marambaia Island and the use of some CADIM facilities during the fieldwork.

\section{References}

BERTO, B. P. et al. Isospora cagasebi sp. nov. (Apicomplexa, Eimeriidae) from the bananaquit, Coereba flaveola of Brazil. Acta Parasitologica, v. 53, n. 2, p. 117-119, 2008.

BURNS, K. J.; HACKETT, S. J.; KLEIN, N. K. Phylogenetic relationships of Neotropical honeycreepers and the evolution of feeding morphology. Journal of Avian Biology, v. 34, n. 4, p. 360-370, 2003.

COMITÊ BRASILEIRO DE REGISTROS ORNITOLÓGICOS CBRO. Lista das Aves do Brasil. Rio de Janeiro: CBRO, 2009. 38 p.

DUSZYNSKI, D. W.; WILBER, P. G. A guideline for the preparation of species descriptions in the Eimeridae. Journal of Parasitology, v. 83, n. 2, p. 333-336, 1997.

GRULET, O.; LANDAU, I.; BACCAM, D. Les Isospora du Moineau domestique; multiplicite des especes. Annales de Parasitologie humaine et Compareè, v. 57, n. 3, p. 209-233, 1982.

RAFFAELE, $H$. et al. A Guide to the Birds of the West Indies. Princeton: Princeton University Press, 1998. 500 p.

SAMPAIO, I. B. M. Estatística aplicada à experimentação animal. 2. ed. Belo Horizonte: FEPMVZ, 2002. 265 p.

SICK, H. Ornitologia Brasileira. Nova Fronteira: Rio de Janeiro, 1997. 862 p. 